Relations industrielles

Industrial Relations

\title{
Industrial Relations in the Organized Plant
}

\section{W.-E. Curry}

Volume 4, numéro 4, décembre 1948

URI : https://id.erudit.org/iderudit/1023461ar

DOI : https://doi.org/10.7202/1023461ar

Aller au sommaire du numéro

\section{Éditeur(s)}

Département des relations industrielles de l’Université Laval

\section{ISSN}

0034-379X (imprimé)

1703-8138 (numérique)

Découvrir la revue

Citer cet article

Curry, W.-E. (1948). Industrial Relations in the Organized Plant. Relations

industrielles / Industrial Relations, 4(4), 38-40. https://doi.org/10.7202/1023461ar

Tous droits réservés @ Département des relations industrielles de l’Université Laval, 1948
Ce document est protégé par la loi sur le droit d'auteur. L'utilisation des services d'Érudit (y compris la reproduction) est assujettie à sa politique d'utilisation que vous pouvez consulter en ligne.

https://apropos.erudit.org/fr/usagers/politique-dutilisation/ 
TABLE 3: MINIMUM WAGES FOR THE TRADE OF BRICKLAYER IN THE PROVINCE OF QUEBEC 1934-1948 ${ }^{1}$

\begin{tabular}{|c|c|c|c|c|c|c|c|c|c|c|c|c|c|c|c|c|}
\hline DISTRICTS & 1934 & 1935 & 1936 & 1937 & 1938 & 1939 & 1940 & $194 !$ & $194 ?$ & 1943 & 1944 & 1945 & 1946 & $19 \div 7$ & 1918 & $\begin{array}{l}\text { Absolute } \\
\text { increase }\end{array}$ \\
\hline Chicoutimi & $\ldots$ & .70 & .70 & .70 & .70 & .70 & .75 & .80 & .85 & .85 & .85 & .90 & 1.00 & 1.05 & 1.15 & .45 \\
\hline Abitibi * & $\ldots$ & $\ldots$ & $\ldots$ & $\ldots$ & $\ldots$ & $\ldots$ & $\ldots$ & .75 & .75 & .75 & .80 & .80 & 1.00 & 1.05 & 1.15 & .40 \\
\hline Hull & $\ldots$ & .90 & .90 & .90 & 1.00 & 1.00 & 1.00 & 1.00 & 1.00 & 1.05 & 1.05 & 1.15 & 1.25 & 1.25 & 1.25 & .25 \\
\hline Joliette & .60 & .60 & .60 & .60 & .60 & .60 & .60 & .60 & .60 & .65 & .75 & .75 & .85 & .90 & 1.00 & .40 \\
\hline Montréal & .70 & .70 & .70 & .80 & .80 & .80 & .88 & .92 & .97 & .97 & 1.05 & 1.06 & 1.17 & 1.17 & 1.40 & .60 \\
\hline Québec & .70 & .70 & .70 & .75 & .75 & .75 & .80 & .85 & .90 & .90 & 1.00 & 1.00 & 1.10 & 1.15 & 1.20 & .45 \\
\hline Saint-Hyacin the & $\cdots$ & .50 & .50 & .55 & .65 & .65 & .65 & .70 & .70 & $.771 / 2$ & .85 & .85 & .95 & 1.00 & 1.05 & .40 \\
\hline Saint-Jean & $\cdots$ & $\cdots$ & $\cdots$ & $\cdots$ & .65 & .65 & .70 & .70 & .78 & .78 & .78 & .78 & .88 & .90 & 1.17 & .52 \\
\hline Sherbrooke & .60 & .60 & .60 & .60 & .65 & .65 & .80 & .85 & .85 & .90 & .90 & 1.00 & 1.00 & 1.10 & 1.20 & .55 \\
\hline Drummond $\ddagger$ & $\ldots$ & .55 & .55 & .55 & .60 & .60 & .75 & .75 & .75 & .80 & .80 & .95 & .95 & 1.05 & 1.15 & .55 \\
\hline Sorel & $\ldots$ & $\cdots$ & $\ldots$ & .55 & .60 & .60 & .60 & .60 & .60 & .65 & .75 & .75 & .95 & 1.10 & 1.10 & .50 \\
\hline Terrebonne & $\cdots$ & $\cdots$ & $\ldots$ & $\ldots$ & $\ldots$ & .60 & .75 & .85 & .90 & .90 & .95 & .95 & 1.05 & 1.05 & 1.15 & .55 \\
\hline Trois-Rivières & .70 & .70 & .70 & .70 & .70 & .70 & .80 & .85 & .90 & .95 & .95 & .95 & 1.00 & 1.10 & 1.20 & .50 \\
\hline
\end{tabular}

1 Decrees pursuant to the Collective Agreement Act. In the regions comprising more than one zone the rates mentioned are those of Zone I.

* Subject to a Decree in force in the Chicoutimi region since March 30, 1948.

+ Subject to a Decree in force in the Sherbrooke region (Zone II) from 1936 to 1947 inclusive.

\title{
INDUSTRIAL RELATIONS IN THE ORGANIZED PLANT
}

\author{
W. E. Curky
}

At the outset, mey we say that in presenting our Company's approach to industrial relations, we do not wish to imply that we have reached an advanced degree of perfection or, even of progressiveness, but we do feel that we are on the way. We would like to review some of the activities which we think have been of value to us and discuss briefly our philosophy of industrial relations on which we are basing future plans.

\section{The Problem Defined}

Christian democracy has taught men to aspire toward greater and greater self-realization and self-expression. It has preached the dignity and worth of the individual man. At the same time our present-day mass production society has been reducing the opportunities offered the individual to secure that self-expression. Mass production industry, while creating enormous quantities of goods at low prices, has submerged the individual worker in the flow of production to the point where he is losing, or has lost, all feeling of individual identity, or sense of participation in the enterprise.

It is our belief that the survival of this capitalistic system of ours depends in no small measure on the ability of modern industry to protect the dignity and selfrespect of the ordinary working man. There is no force in society, other than industrial management capable of solving the problem. If we do not succeed the working man will turn out of sheer frustation to another form of society, even though in many ways a less desirable one.

\section{The Search for a Solution}

In seeking an answer in our company, we have put emphasis on the basic atitude of management - of all management - towards the employees generally. Real personnel work is in the last analysis, carried out by the line or the operating organization. If management is genuinely interested in the people it employs and in their progress as individual human beings and makes an effort to express this interest the details will for the most part take care of themselves.

In our view, an Industrial Relations or Personnel Department serves its best purpose in helping to bridge the gap existing between management and labor created by the physical size of modern plants and by mass production factory methods. It is one of the avenues through which management expresses its interest in the employees of the company. 
Industrial Relations is a staff department, without authority or power, relying for its acceptance entirely on the independence of its position and the objectiveness of its thinking. We believe it is essential that the Personnel Manager remains free from any suggestion of possessing direct authority over anyone other than his own staff.

\section{Electrohome's Program of Industrial Relations}

\section{Written Personnel Policies}

In our programme of industrial relations we start with written personnel policies. This has become a recognized " must 》 in most of the larger companies today. We are reminded of the story of a metal fabricating plant in the State of Washington. They had their policy in writing on a large sign hanging in the middle of the plant which said: «If you enjoy work, you can have a hell of a lot of fun here ». We would hardly regard this as an adequate statement of personnel policy but at least it lets everyone know where management stands!

In this connection, we believe all companies should have a philosophy of management which is expressed in writing. The materialistic desire for profits is no longer a sufficient basis upon which to build a business. There must be something broader and deeper in the purpose of a company to give it vitality and appeal.

Our labor policy provides us with the basic starting point from which all other policies are derived, and is as follows:

«It shall be the Company's constant endeavour to treat the men and women in its employ fairly and in good faith. Every effort shall be made, through training and leadership to develop and utilize to the full each individual's skill and ability. It is the Company's belief that, only by bringing out the best efforts of each member, can the Company be assured of success and can the men and women, who carry out the work of the Company, feel satisfied and secure. 》

These statements seem to be self-evident and trite, having no more than general significance. Yet when it is realized that they contain a number of promises, it becomes obvious hat a procedure must be created to see that the policy is carried out. When we say we will treat employees «fairly», we are guaranteeing them against arbitrary discharge, against discrimination. We are, in effect, promising them fair wages and merit increases. This involves merit rating, job evaluation, a separation procedure, and other protective policies.

\section{Selection and Placement}

We place strong emphasis on the careful selection and placement of personnel. To that end, we have developed and have used for a number of years, an extensive psychological testing program which, together with personal interviewing and followup, helps place people in the right jobs. This, after all, is the first step in making sure that the worker has an opportunity of protecting his self-respect and of developing his skills and abilities.

\section{Personnel Development}

We believe that the employee deserves the right to be well trained for his job and well supervised. To this end, we are working on a personnel development and educational program in which particular emphasis is placed on foremen development. Skill-less mass production operators are dependent to a great degree on their foremen for job satisfaction, and for this reason we believe it essential that foremen be good leaders.

Another feature of this plan is to assist employees with any educational endeavour, which they wish to undertake, whether related to Company activities or not. This again encourages self-expression and self-realization among the members of the working force.

\section{Safety and Health}

We believe employees deserve to be well protected on the job. Safety training compulsory use of safety equipment, and regular safety inspections, have had the result of cutting our accident frequency and severity steadily year by year to its present very low rate

Plant music is provided before the shift commences and during two 10-minute periods morning and afternoon. The canteens afford healthy spots to go during rest and lunch periods Hospitals in each of the plant, with fulltime registered nurses in attendance and a part-time staff doctor, help keep the health of our personnel at a good level. We have had good results from both employment and periodic medicals.

This concern for an employee's safety comfort and health gives him tangible evidence of the Company's interest in his welfare as an individual.

\section{Participation by Employees}

We believe in collective bargaining. Not only does the employee gain from union membership, a sense of participation in decisions affecting him, but he no longer feels completely at the mercy of a great impersonal machine. Moreover, the Company gains through having trouble reach the surface quickly where it can be taken care of, rather than being allowed to build up to serious proportions before being discovered.

The union is represented on wage, suggestion, safety, and special committees, and it is consulted well in advance regarding developments which will have an effect on personnel. Top management sits down monthly in a union-management committee to discuss over-all problems. We have found this helpful in keeping each other informed regarding what is going on.

A sense of participation in the business is further built up through the suggestion plan, the plant newspaper. and through a policy of telling employees as far in advance as possible about changes that will affect them and about what is happening in the Company as a whole. In this latter regard you will agree that human beings resist change. According to our experience it is well to break new ideas slowly. We believe it is best to bring forward a new idea as a suggestion or as a possible development well before it is to be put into operation. Then when the time for introduction comes it is no longer new. The union will have had a chance to think it over and most of the resistance will have been eliminated. We do not think there is any more frequent single cause of personnel discontent than this failure on the part of top management to take the various levels of supervision and the operators into their confidence, in advance, regarding changes or developments that will affect them.

An official of Bridgeport Brass Company recently said: \& Treat a man as your equal, respect his integrity, give him all the facts; and he'll be entirely reasonable $\gg$. This, after all, is a principle upon which our democratic system rests. 


\section{Fair Wages}

We believe in a wage and salary plan which will keep our wages in line with or above those of the rest of the community and which provides an equitable part of our program. Job evaluation merit rating, and incentive pay, are all a part of the plan. In our opinion, our employees appreciate that job evaluation is a protection for them from favoritism and that it takes much of the guesswork out of wage administration.

\section{Security}

We believe in promoting employee security, but only to the extent of helping the employee help himself. The desire for full security has been accepted by the public at large as a just and attainable objective. In our view, this is an unhealthy situation, as full security can only be attained at the cost of freedom. However, in the modern industrial world the ability of the average worker to provide for his own security has been seriously weakened, and industry must help fill the gap created. Basic security, on our Company, is promoted through stability of employment, profit sharing, promotion from within, long service recognition, and group sickness and benefit plans.

\section{Personnel Planning and Research}

We believe that a research approach to industrial relations is a fundamental need for the achievement of adequate progress and for the finding of a solution to the human relations problem confronting industry today. When a certain distinguished scientist was asked what coming invention would mean most to mankind, he replied: \&I don't think any invention will mean so much to mankind as the discovery of a better way to get along together.»

We have too long felt we understood what the worker wants in the way of satisfaction from his job. We have too long disregarded the study of how groups of people react to changes in their social and economic environment. Professor Line of the University of Toronto in speaking to the Toronto Personnel Association last winter commented as follows:

«It is said that we professors live in ivory towers far from the world of reality. It may turn out that it is the business man who is living in the ivory tower of materialism - in a world of his own imagination far from the realities of human relations and from an appreciation of the aspirations and attitudes of the factory operator. »
Many of our universities following the lead of Princeton, Harvard and Chicago, are doing valuable work in the field of industrial relations research, including the University of Toronto, Queen's University, and at least two of the Quebec universities. This activity is worthy of the full support of the manufacturers of Canada. Just over a year ago Mr. Henry Ford was quoted as saying:

«Perhaps for every dollar we spent in scientific research for the development of better products and more efficient machines we should have spent another dollar in research into the problems of people in industry. 》

In our view there is much truth in this statement, and we have worked as closely as possible with the universities.

Basically, this is the industrial relations program of our Company. There is much left to be done, we have many shortcomings but we hope we are on the right track.

\section{Conclusion}

We would like to conclude these remarks with a statement of personal belief:

Good industrial relations is not a costly thing involving a large staff and the employment of experts. Nor does good industrial relations consist of a packaged personnel program copied from another company's succesful plan. Good industrial relations is an attitude of mind on the part of the men running the company. If top management has a sincere desire to understand the attitudes, expectations, and dreams of their people, and constantly works to satisfy them as far as is legitimately possible, we will make a good progress in restoring to our mass production society the stability, the group co-operation, and human satisfactions that we seem to have lost. Without such an attitude, the industrial relations program is at best a palliative restraining industrial unrest.

« The final answer to good human relations lies not in laws, not in compulsion, not in conciliation services, not in elaborate grievance procedurese; the answer is in leadership, based on human understanding; there is no other way to industrial peace. 》

"Industrial Canada"

\section{Structural Refarms in Enterprise}

A booklet containing a reproduction of the articles published in the "Bulletin des relations industrielles" by Messrs. P.-E. Bolté, Marcel Clément and Gérard Dion will soon be obtainable at the Department of Industrial Relations of Laval University. 